\title{
The Effect Of Leadership Style, Job Satisfaction And Employee-Supervisor Relationship On Job Performance And Organizational Commitment
}

\author{
Sunday Samson Babalola, Ph.D., University of Venda, South Africa
}

\begin{abstract}
Although organizational commitment and job performance are essential for the survival of an organization, yet scanty attention is paid to simultaneous study of these variables. This study set to investigate the influence of supervisor-employee relationship, perceived leadership style, and job satisfaction on organizational commitment and job performance. Two hundred and fifty-five employees of media employees are conveniently sampled with ages ranging from 20 to 57 years with a mean of 34.29 years. Stepwise multiple regression analysis was employed to test the working hypotheses.
\end{abstract}

Stepwise regression analysis reveals three steps in the prediction of organizational commitment and job performance respectively. With the third step shows that job satisfaction $(\beta=0.53 ; p<.001)$; supervisorsubordinate relationship $(\beta=0.41 ; p<.001)$ and laissez-faire leadership styles $(\beta=0.38 ; p<.001)$ are the predictor of organizational commitment with 49.7\% variance is explained; while with job performance, $34.8 \%$ of variance explained the variables of working experience $(\beta=-0.54 ; p<.001)$; education $(\beta=0.31 ; p<.01)$ and transformational leadership styles $(\beta=-0.22 ; p<.05)$. This finding has implications for employee retention, performance management and incentive strategy.

Keywords: Job Performance, Commitment, Transformational Leadership, Job Satisfaction, Laissez-Faire

\section{INTRODUCTION}

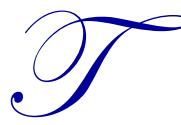

odays' work places are more complex and sophisticated requiring erudite leadership due to global economic competitiveness, as leaders are confronted with unpredictable challenges, which require different degree of leadership management. Effective management of employees may be assumed to be achievable through leadership behavior, which promotes employee's commitment and productivity. Although, employees' performance can be highly affected by many factors arising from within and outside organizational context (Islam, Khan, Shafiq, \& Ahmad, 2012).

Performance can be viewed as multi-dimensional concept. For instance, Borman \& Motowidlo (1993) distinguished between task and contextual performance. Task performance refers to an individual's proficiency with which activities that are performed contribute to the organization's 'technical core'. Such contribution can either be direct (in the case of production employees), and indirect (in the case of human resource employees) or both. Contextual performance refers to activities, which do not contribute to the technical core but support the organizational social environment in the pursuant of the organizational goals. Contextual performance includes behaviours such as helping co-workers, being a reliable member of the organization and performing activities that help to improve work procedures.

Job satisfaction refers to the extent that the working environment meets the needs and values of employees and the individual's response to that environment (Lambert, 2004; Tewksbury \& Higgins, 2006). It is the affective feelings 
that people have about their jobs. No wonder, Robins (2005) study shows that employees with high job satisfaction behave differently from employees with low job satisfaction. Similarly, job satisfaction is also related to many job outcomes (Spector, 2000) such as job performance (Gebauer \& Lowman, 2009; Macey \& Schneider, 2008; Macey, Schneider, Barbera, \& Young, 2009). The leadership style of managers and the job satisfaction of subordinates have been found to have salient effects on subordinate work outcomes (Spector, 2000). Therefore, adopting a leadership style that works best for an organization and its employees remains one of the most effective and efficient means by which organizations achieve their objectives and that of employees' satisfaction.

The concepts under focus have been researched more in the developed economies with various conclusions, many of which may be at variance with what may be obtainable in the developing economies due to operational cultural dispositions to work. This study therefore examines the influence of leadership style, supervisor-subordinate relationship and job satisfaction on work behaviour (commitment and performance). The result from this research is expected to benefit management of organizations through the understanding of the influence of leadership style.

\section{LITERATURE REVIEW}

One of the underlying theories in this study is social exchange theory. According to social exchange theory, as individual employees interact overtime, such employees' experience the need to reciprocate the support and assistance receives from other employees. Blau (1983) described such relationship as norm of reciprocity. When the norm of reciprocity is fulfilled, a trusting and loyal relationship evolves among employees (Cropanzano \& Mitchell, 2005). As a result, the individual employees feel more motivated to reciprocate a favour than what the benefactors may actually predict (Flynn, 2003; McGuire, 2003). Social exchange theory has been used to explain how organizations implement and practice a range of mentoring activities or generate ideas for job design, which enable employees feel the organization support and trust them. As a consequent, the employee develops commitment to the organization, thus resulting in job improvements and performance (Piening, Baluch, \& Salge, 2013).

The dual pathway model of respect by Huo, Binning, and Molina (2010) explain the two pathways that underpin the benefits of respect. First, the employees tend to assume the respect they receive symbolizes their status in the organization. That is, when managers treat employees respectively and fairly, employees feel their skills and talents are perceived as valuable to the organization or work-team. Such perceptions promote self-esteem and confidence in their skill. Second, the employees also assume that the respect receive demonstrate likeness and belongingness. That is, employees tend to enter into exchange when they perceive the accruable benefit as a result of being part of the system. This enables them to engage in mental bookkeeping that involves ledger of rewards, costs and profits. Simply put, an employee will continue on a job as long as it continues to be rewarding. Relationship may also be meaningful to the subordinates when the action of the supervisor protects their interest. For example, a positive relationship that is mutual may result in employees' high level of commitment and job performance. According to Robins (2005), relationship between supervisors and subordinates is vital, because of its benefits in terms of organizational effectiveness, employees' career development and wellbeing. That is, healthy supervisor-subordinate relationship can affect work outcomes positively.

The investment model of commitment states that commitment is not only affected by the outcome of values of the current relationship and alternatives, but by the amount of investment contribution to the relationship (Rusbult, 1980). Investment is referred to as the resource that is "put into" an association, with the aim of improving the longterm value of the relationship. Common investments are length of service, acquisition of non-profitable skills and retirement programmes. Working from the investment model, Arriaga and Agnew (2001) define commitment as a psychological state involving affective, cognitive and conative components. Affective component involves psychological attachment with a relationship; cognitive component entails assumption of a long-term orientation; and lastly, conative component is the intention to persist. This study is relying on the assumption that employees construct commitment across the three-components of identification with an organization, long-term orientation, and intention to persist. According to McMahon (2007) an employee who performs his/her duty out of a sense of obligation may persist in the relationship due to internalized norms that compel the employee to feel a sense of obligation to work for the organization. This is in line with investment model, which specifies that the final determinant of commitment is investment size. 
Research indicates that tenure is positively related to organizational commitment (Meyer \& Allen, 1997), though; it is still not clear how this link operates. A possible explanation may be as employee's length of service increases; such employee develops emotional attachment with the organization, which makes it difficult to switch jobs. Similarly, a positive relationship between tenure and organizational commitment might be a reflection of the fact that uncommitted employees leave an organization while those with a high commitment remain (Meyer \& Allen, 1997). Study by John and Taylor (1999) indicate that education is expected to have a negative relationship with organizational commitment because employees with low levels of education generally have more difficulty changing jobs and therefore show greater commitment to the organizations.

Herzberg's two-factor theory provides a theoretical framework for scientifically assessing job satisfaction (Zhao, Thurman, \& He, 1999). Herzberg's theory claims that the work environment determines job satisfaction in three main areas: the work itself; the responsibility one has in the work; and recognition received from performing the work (Brody, Demarco, \& Lovrich, 2002; Zhao, et al., 1999). Researchers such as Robins (2003) and McShane \& VonGlinow (2000) report strong relationship between job satisfaction and organizational commitment, while findings from scholars such as Fatokun (2007) and Ogunyinka (2007) show that the relationship between job satisfaction and organizational commitment is weak and that job satisfaction may not necessarily lead to organizational commitment. As Camp (1994) reports that low levels of job satisfaction among employees is associated with attendance problems, higher rates of turnover, lack of active participation in job tasks, and psychological withdrawal from work. Generally, literature suggests that employees are better satisfied with their jobs when they are adequately recognized for a job well done and when they have an opportunity to contribute to policies and procedures of the organization (Slate, Wells, \& Johnson, 2003).

There are a number of studies that relates leadership style to organizational commitment. According to Robins (2005), the adoption of appropriate leadership style influence subordinates to develop trust in management and commitment. In their study, Dale and Fox (2008) state that superiors that engage in leadership style, which support, respect, trust and friendly are more likely to interact with employees on professional, emotional, and spiritual levels. Just as Morris and Sherman (1981) equate high levels of social interaction between the leader and subordinates with higher levels of organizational commitment, as employees with social ties to the organization may not voluntarily severe professional, social and emotional ties.

Organization as a system, transforms employees' effort and physical resources into products or services in the same way effective leadership actions influence organizational transformation process and adaptation (Fleishman, Mumford, Zaccaro, Levin, Korotkin, \& Hein, 1991). In view of this, DeRue, Nahrgang, Wellman, and Humphrey (2011) suggest that leadership models should focus more on identifying proximal variables (behaviours), which may have strong predictive validity as distal predictors are useful for predicting broad behavioural tendencies (Connelly, Gilbert, Zaccaro, Threlfall, Marks, \& Mumford, 2000). As Howell and Avolio (1993) study indicates relationships between transformational leadership styles and performance outcomes, Dvir, Eden, Avolio, and Shamir (2002) study show that transformational leadership had an indirect impact through a layer in the hierarchy on the performance. However, Wang, Law, Hackett, Wang, and Chen (2005) show that leadership has major influence on employees' performance and commitment without reference to leadership style. While Islam, et al (2012) wrote that leadership styles have greater impact on employees job related behaviour such as work performance.

According to the leader-member exchange theory, a good quality 'dyadic' relationship resulting from the leader's treatment of the subordinates tend to promote higher performance rating (Linden, Wayne, \& Stilwell, 1993), stronger organizational commitment (Nystrom, 1990), and higher overall satisfaction (Scandura \& Graen, 1984). While Nystrom (1990) study reports that managers that experience low-quality exchanges with their line managers tend to show weak organizational commitment, whereas managers with high-quality exchanges express strong organizational commitment.

Changes in demography have been identified as one of the factors that affect work performance (Palakurthi \& Parks, 2000). Though, there are few studies that investigate the impact of demographic factors on work performance. One of such is Linz (2002) study, which show that the level of education does not influence work performance. On the other hand, Ariss and Timmins (1989) indicate that education to some extent affect work performance because the lower the education level, the less likely people would have better work performance. While, McBey and 
Karakowsky (2001) findings show a causal relationship between education and work performance.

Judge, Thoresen, Bono, and Patton, (2001) meta-analysis result show a stronger and positive link between performance and job satisfaction than previously accepted. Berta (2005) alludes to the fact that job satisfaction is linked to experience of positive relationships with co-workers, enjoying the work itself, and supervisors' performance. Similarly, Jones (2005) finding shows that job satisfaction is a result the amount of prestige the outsiders associated with their job. These findings seem to show the factors, which can help improve the employees' job satisfaction, may not be cost prohibitive for organizations to implement. This study will therefore test the following hypotheses:

1. Work experience, education, supervisor-employee relationship, perceived leadership style, and job satisfaction will independently influence organizational commitment.

2. Work experience, education, supervisor-employee relationship, perceived leadership style, and job satisfaction will independently influence job performance.

\section{METHODOLOGY}

\section{Research Design and analysis}

The study is based on cross sectional survey research design as no variables examined are manipulated. The predictor variables are work experience, education; perceive leadership style, supervisor-subordinate relationship and job satisfaction while the criteria variables are organizational commitment and job performance. The data are analyzed using Statistical Package for Social Sciences. Specifically, stepwise multiple regression analysis is employed to test the strength of the prediction of demographic and psychological variables on the criteria variables of organizational commitment and job performance.

\section{Participants}

One hundred and twenty-three media employees in Oyo state, Nigeria are participants in this study. Participants' age ranges from 20 to 56 years with a mean of 33.72 years and work experience ranging from 1 to 29 years with a mean of 6.91 years. Sixty-five per cent of participants were men, while their women counterparts were $34 \%$. Their levels of education ranged from Diploma (44\%) and university degree $56 \%$. On the job positions of the participants, $45.5 \%$ were junior employees; those in supervisory capacity were 39.6\%) while management officers were $14.9 \%$. About Forty-six per cent $(45.7 \%)$ were single while $54.3 \%$ were married.

\section{Instrument}

Structured questionnaire is used to collect relevant information from the participants in the study. The questionnaire contains information such as sex, age, educational level, work experience, supervisor-subordinate relationship, leadership style, job satisfaction, organizational commitment and job performance measures.

Supervisor-subordinate relationship is 11-item measures developed and refined by researchers at the Margaret Blenkner Research Institute (Noelker \& Ejaz, 2001). This measure taps the degree of frequency with which supervisors demonstrate good communication, recognition and team building abilities. The measure is anchored on a 5-point Likert rating scale from strongly agree (5) to strongly disagree (1). Higher scores reflect positive perception of supervisor by subordinates while lower scores represent negative perception of supervisor-employee relationship. It has internal consistency of alpha coefficient of 0.90 . In terms of validity, better relationships with supervisors are correlated with higher levels of positive interaction with other staff members $(r=.21, p<.001)$. In this study, the scale yielded reliability alpha coefficient of 0.74 .

Organizational commitment scale (Mowday, Steers, \& Porter, 1979) which consists of 15 items and anchored on a 5-point Likert scale response ranging from strongly agree (5) to strongly disagree (1) is used to measure organizational commitment. It has both negatively and positively worded items, with each negative phrased statement are reversed, while positively worded items are scored positively. The psychometric property of this scale 
has been reported in previous studies (e. g. Mowday, et al., 1979) with internal consistency for the scale ranged from .0 .80 to 0.90 . The 15 items in the scale in the current study yielded reliability alpha coefficient of 0.65 .

The Multifactor leadership questionnaire (MLQ - Form 5X) represents nine single-order factors comprised of five transformational leadership factors, three transactional leadership factors, and one laissez-faire leadership (Bass, 1998; Bass \& Avolio, 1994). The nine leadership factors, which contain 36-item, are used to assess three leadership outcomes (Avolio, Bass, \& Jung, 1999). Transformational leaders are proactive, raise follower awareness for transcendent collective interests, and help followers achieve extraordinary goals. The 20-item measuring transformational leadership style is loaded on 5-factor of idealized influence (attributed), idealized influence (behaviour), inspirational motivation, intellectual stimulation, and individualized consideration. Transactional leadership is an exchange process based on the fulfilment of contractual obligations and is typically represented as setting objectives and monitoring and controlling outcomes. The transactional leadership style is loaded on three factors of contingent reward, management-by-exception (active), and management-by-exception (passive) with 12item measure. Laissez-faire leadership represents the absence of a transaction of sorts with respect to leadership in which the leader avoids making decisions, abdicates responsibility, and does not use his/her authority. It is generally considered the most passive and ineffective form of leadership and is measured with 4-item. These items were rated using a 5 -point Likert scale with label as $1=$ not at all, $2=$ once in a while, $3=$ sometimes, $4=$ fairly often, $5=$ frequently, if not always.

A 10-item job satisfaction scale (Macdonald \& Maclntyre, 1997) is used to measure overall job satisfaction levels of participants. It has a reliability alpha coefficient of 0.77 , while the current study shows a reliability alpha coefficient of 0.64. The measurement is on the Likert-type scale ranges from disagree strongly (1) to agree strongly (5). The scoring procedure indicates the high score implies high job satisfaction and low score, low job satisfaction.

Wright, Kackmar, McMahan, and Deleeuw's (1995) 10-item job performance scale formatted in Likert degree of response ranging from strongly agree (5) to strongly disagree (1) is adopted as a self-report measure. The scoring procedure for this scale is such that high scores reflect higher level of job performance, while lower scores represent lower job performance. The reliability alpha coefficient for the scale has been confirmed in previous studies (Wright, et al., 1995). The current study has 0.82 reliability alpha coefficients for the 10 - item scale.

\section{Procedure}

Official approval from university ethical committee and the management of the newspaper paper organizations are obtained before the administration of questionnaires. The Human Resource Section of the organization assists in distribution and collection of the questionnaires. Also, informed consent of the participants is sought with only those that append their signatures finally participate in the study. From the three hundred copies of the questionnaire administered to the employees, one hundred and eighty were retrieved, while others were either invalidated as a result inappropriate responses or were not retrievable. However, 123 questionnaires were properly filled which were then subjected to data analysis after collation, scoring and coding.

\section{RESULTS}

Table 1 shows supervisor-subordinate relationship to be positively correlated with organizational commitment $(\mathrm{r}=$ $.44, \mathrm{p}<.01)$, and job performance $(\mathrm{r}=.28, \mathrm{p}<.01)$. Similarly, job satisfaction correlate positively with organizational commitment $(\mathrm{r}=.39, \mathrm{p}<.01)$, and job performance $(\mathrm{r}=.20, \mathrm{p}<.05)$. Transformational leadership style positively correlate with transactional leadership style, $(\mathrm{r}=.71, \mathrm{p}<.01)$; and negatively correlate with laissezfaire leadership style, $(r=-.20, p<.05)$, and job performance, $(r=-.29, p<.01)$. Whereas, transactional leadership style is positively correlate with laissez-faire leadership style $(\mathrm{r}=.22, \mathrm{p}<.01)$, and also negatively relate with job performance $(r=-.25, \mathrm{p}<.01)$. 
Table 1. Mean, Standard deviation and relationship between supervisor-subordinate, job satisfaction, leadership styles, organizational commitment and job performance

\begin{tabular}{l|c|c|c|c|c|c|c|c|c|c}
\hline & Mean & SD & N & SuR & JS & Transf & Transac & Lfaire & Commit & JPerf \\
\hline SuR & 25.48 & 4.291 & 123 & 1 & -.02 & -.03 & -.09 & -.00 & $.44^{* *}$ & $.28^{* *}$ \\
\hline JS & 11.90 & 3.325 & 123 & & 1 & .04 & .13 & -.14 & $.39^{* *}$ & $.20^{*}$ \\
\hline Transf & 67.37 & 13.976 & 123 & & & 1 & $.71^{* *}$ & $-.20^{*}$ & .09 & $-.29^{* *}$ \\
\hline Transac & 30.11 & 6.840 & 123 & & & & 1 & $.22^{* *}$ & .12 & $-.25^{* *}$ \\
\hline Lfaire & 6.70 & 2.473 & 123 & & & & & 1 & .11 & -.04 \\
\hline Commit & 37.33 & 5.066 & 123 & & & & & & 1 & .05 \\
\hline JPerf & 18.39 & 3.117 & 123 & & & & & & 1 \\
\hline$* *$
\end{tabular}

$* *=\mathrm{p}<0.01$ level; $*=\mathrm{p}<0.05$ level.

Note: $\mathrm{SuR}=$ supervisor-subordinate relationship; JS $=$ job satisfaction; Transf $=$ transformational leadership style; Transac $=$ transactional leadership style; Lfaire = laissez-faire leadership styles; Commit = organizational commitment; JPerf = job performance.

Stepwise regression analysis is conducted in which education; work experience, supervisor-subordinate relationship, job satisfaction, transformational, transactional, and laissez-faire leadership styles are entered as predictors and organizational commitment as an outcome variable. Step 1 in table 2 , indicates that job satisfaction $(\beta=.44, \mathrm{p}<$ .001 ) is the most conspicuous positive predictor of organizational commitment causing $19.5 \%$ variance in explanation, $\mathrm{F}(1,69)=16.68, \mathrm{p}<.001$.

Step 2 reveals that supervisor-subordinate relationship is the second important predictor of organizational commitment and $36.6 \%$ variance is explained by the predictors, $\mathrm{F}(2,68)=19.59, \mathrm{p}<.001$, indicating that addition of supervisor-subordinate relationship lead to $17.1 \%$ increase in organizational commitment. Detail result shows that job satisfaction $(\beta=.43, \mathrm{p}<.001)$ and supervisor-subordinate relationship $(\beta=.41, \mathrm{p}<.001)$ have significant distinctive effect on organizational commitment.

Step 3 depicts that laissez-faire leadership style is the least important predictor of organizational commitment and $49.7 \%$ variance is explained by the predictors, F $(3,67)=22.11, p<.001$, with laissez-faire leadership style showing increase of $13.2 \%$ of variance in organizational commitment. The full result indicates that job satisfaction $(\beta=.53, \mathrm{p}<.001)$, supervisor-subordinate relationship $(\beta=.41, \mathrm{p}<.001)$ and laissez-faire leadership style $(\beta=.38$, $\mathrm{p}<.001$ ) have significant positive effect on organizational commitment.

Table 2. Stepwise regression analysis showing the effect of predictor variables on organizational commitment

\begin{tabular}{l|c|c}
\hline \multicolumn{1}{|c|}{ Predictor } & $\Delta \mathbf{R}^{2}$ & $\mathbf{B}$ \\
\hline Step 1 & $\mathbf{. 2 0}$ & $.44^{* * *}$ \\
$\quad$ Job satisfaction & .17 & $.43^{* * *}$ \\
\hline Step 2 & & $.41^{* * *}$ \\
$\quad$ Job satisfaction & & $.53^{* * *}$ \\
\hline Supervisor-subordinate relationship & .13 & $.41^{* * *}$ \\
\hline Step 3 & & $.38^{* * *}$ \\
\hline Job satisfaction & & \\
\hline Supervisor-subordinate & & \\
\hline Laissez-faire leadership styles & & \\
\hline
\end{tabular}

Hypothesis two, which states that education, work experience, supervisor-employee relationship, leadership style (transformation, transactional and laissez-faire) and job satisfaction is independently and jointly predict job performance is tested using stepwise multiple regression analysis. The result is presented in Table 3 . Step 1 indicates that working experience $(\beta=-.46, \mathrm{p}<.001)$ is the most obvious a negative predictor of job performance producing $21.4 \%$ variance, $\mathrm{F}(1,69)=18.83, \mathrm{p}<.001$. 
Table 3. Stepwise regression analysis showing the effect of predictor variables on job performance

\begin{tabular}{l|cc}
\hline \multicolumn{1}{|c|}{ Predictor } & $\Delta \mathbf{R}^{2}$ & $\mathbf{B}$ \\
\hline Step 1 & $\mathbf{2 1}$ & $-.46^{* * *}$ \\
$\quad$ Work experience & $\mathbf{. 0 9}$ & $-.54^{* * *}$ \\
\hline Step 2 & & $.31^{* *}$ \\
$\quad$ Work experience & & $-.51^{* * *}$ \\
\hline Education & $\mathbf{0 5}$ & $.31^{* *}$ \\
\hline Step 3 & & $-.22^{*}$ \\
\hline Work experience & & \\
\hline Education & & \\
\hline Transformational leadership styles & & \\
\hline
\end{tabular}

Step 2 reveals that education is the second most important predictor of job performance with $30.2 \%$ variance explained by the predictors, $\mathrm{F}(2,68)=14.75, \mathrm{p}<.001$, and that the addition of education lead to increase of $8.8 \%$ variance in job performance. Detailed result shows working experience $(\beta=-.54, p<.001)$ as significant negative predictor while education $(\beta=.31, \mathrm{p}<.01)$ has positive significant effect on job performance.

Step 3 depicts that transformational leadership style is the least important predictor of job performance with $34.8 \%$ variance explained by the predictors, $\mathrm{F}(3,67)=11.92, \mathrm{p}<.001$. The result also shows that addition of transformational leadership style increase by $4.6 \%$ of variance in job performance. Specifically, working experience $(\beta=-.51, p<.001)$ and transformational leadership style $(\beta=-.22, p<.05)$ are significant negative predictors, whereas education $(\beta=.31, \mathrm{p}<.01)$ has significant positive effect on job performance. According to this result, working experience is the strongest explanatory variable to explain job performance.

\section{DISCUSSIONS}

The findings from the analyses indicate that job satisfaction and work experience are the most common explanatory variable for organizational commitment and job performance respectively. It also indicates that different leadership style influences the work outcomes. That is, laissez-faire leadership style for organizational commitment while transformational leadership style for job performance.

Specifically, the study revealed that job satisfaction, supervisor-subordinate relationship and laissez-faire leadership style significant influence on organizational commitment with job satisfaction contributing most to organizational commitment than the other exogenous variables. First, there is support for job satisfaction prediction as Spector, (2000) study show it is related to job outcomes. And also the finding of Nystrom (1990) which claimed that employees who perceived the relationship between their line managers and themselves have higher level of organizational commitment than those who did not. The current findings are in agreement with prior studies, which suggest that perceived leadership influences organizational commitment (Dale \& Fox, 2008). Although, the current study highlighted laissez-faire leadership style as predictor of commitment to organization, as against Bycio, et al (1995) and Podsakoff, et al (1996) findings, which found transformational leadership style to lead to stronger organizational commitment. Nevertheless, this finding confirms Wang, et al (2005) assertion that leadership has major influence on work outcome like commitment.

Researchers are of the view that the relationship between job satisfaction and organizational commitment are either not strong or there is weak relationship between the two constructs (Fatokun, 2007; Ogunyinka, 2007). The current study shows a strong influence of job satisfaction on organizational commitment, which also confirm Lok and Crawford (2001) and McNeese-Smith (2001) studies that there is a positive relationship between job satisfaction and organizational commitment.

On the influence of work experience, education, supervisor-employee relationship, perceived leadership style, and job satisfaction on job performance, the result shows that job satisfaction has strong influence on job performance while other exogenous variables are found not to be significant. This is contrary to the result of supervisor-employee relationship on job performance as reported by (Linden, et al., 1993). 
It is also surprising that perceived leadership style do not influence job performance as reported in previous studies (Bass \& Avolio, 1993). Meta-analytic study showed that transformational leadership showed stronger relationship for contextual performance than for task performance while it was positively related to performance at the team and organization levels (Wang, et al., 2011). Although, education and work experience did not have significant joint influence on job performance, the findings however, revealed that only work experience had significant influence on job performance. This is in sharp contrast to what is reported in literature (Palakurthi \& Parks, 2000; Igbaria \& Shayo, 2007; Shaiful, et al., 2009). For instance, McBey and Karakowsky (2001) found that there is likelihood of a causal relationship between education level and work performance. Ariss and Timmins (1989) indicate that education somewhat affect work performance as the lower the education level, the less likely people would have better work performance.

\section{CONCLUSION AND RECOMMENDATIONS}

The study found that job satisfaction, supervisor-employee relationship, and laissez-faire leadership style had significant influence on organizational commitment. It is suggested here that management of the organization understudy should develop programme continue to engage on activities that will encourage not only job satisfaction but good working relationship between superior and subordinate as these contributed more to organizational commitment in the absence of leadership. This may be achieved through the development and training which will take into consideration the needs of employees.

The study also discovered that negative influence of working experience and transformational leadership on job performance should call concern as the management might have been emphasising more on education. Organization therefore, should pay more attention to the attitude and behaviours their employees and its leadership style so as to create pleasant experience for all categories of employees without discrimination whether highly educated or not as many of the experienced workers might not be highly educated. The managers may also needs more training on leadership style as this may aid the organization to do more on job performance for their employees. This finding has implications for the development of loyal employees and incentive strategy. In view of this, managers should make effort to reach out to every member of the organization irrespective of their demographic profiles. This can help in making them better committed to the organization. Star performers should be recognized and compensated accordingly in order to encourage a culture of good performance and commitment.

It was revealed that education and work experience have significant independent influence on job performance. This result implies that demographic variables play some parts in job performance of employees working in Newspaper organizations. There is a need to consider these factors during training, performance management and recruitment of prospective employees. Aligning the personal needs of the employees with those of the organization can be helpful in the development of loyal workforce and performance driven system. Finally the study recommend that management should invest more in uplifting their managerial capacity as this will enhance staff retention policy.

\section{Limitation and Suggestions}

The researchers encumbered by certain factors, which have had effects on the eventual results of the study. Chief among these factors was the research design of the study, which denied the researcher the ability to infer nature of causality. For instance, it is not unlikely that the predictor variables not included in the current study might have significant changes in the criteria variables of the study. Moreover, one cannot say explicitly that the predictor variables that caused changes in the criteria variables and not the other way round. This shows that nature of causation cannot be determined. In addition, the use of self-report instrument to gauge the responses of the participants also has it flaws in increase in the error method variance thereby increasing the superficiality of the relationship between the predictor and criteria variables. In order to improve on the findings of this study, interested researchers may need to adopt an experimental approach in order infer the nature of causation and also have a measurable control over the effect of extraneous variables on the criteria variables. Thus, the use of quasiexperimental research design will suffice. Self-report can also be combined with key informant interview so as to have more explicit findings. 


\section{AUTHOR BIOGRAPHY}

Sunday Samson Babalola is a Professor at the School of Management Sciences, University of Venda. His current research focuses on broadly on Human Capital Management but with emphasis on leadership, dysfunctional work and entrepreneurial behavior. Sunday has published extensively in this field.

\section{REFERENCES}

Ariss, S. S., \& Timmins, S. A. (1989): Employee education and job performance: Does education matter? Public Personnel Management, 18(1), 1- 9.

Arriaga, X. B., \& Agnew, C. R. (2001). Being committed: Affective, cognitive, and conative components of relationship commitment. Personality and Social Psychology Bulletin, 27, 1190-1203.

Avolio, B. J., Bass, B. M., \& Jung, D. I. (1999). Re-examining the components of transformational and transactional leadership using the multifactor leadership questionnaire. Journal of Occupational and Organizational Psychology, 72, 441-462.

Bass, B. M. (1998). Transformational leadership: Industry, military, and educational impact. Mahwah, NJ: Erlbaum.

Bass, B. M., \& Avolio, B. J. (1993). Transformational leadership: A response to critiques. In M. M. Chemers, \& R. Ayman, (Eds.), Leadership theory and Research: Perspectives and directions (pp. 49-80). San Diego, CA: Academic Press.

Bass, B. M., \& Avolio, B. J. (1994). Improving organizational effectiveness through transformational leadership. Thousand Oaks, CA: Sage.

Becker, H. S. (1960). Notes on the concept of commitment. American Journal of Sociology, 66, 32-42.

Berta, D. (2005). Put on a happy face: High morale can lift productivity. Nation's Restaurant News, 39(20), 8-10.

Blau, P. M. (1983). Exchange and power in social life. New York: John Wiley.

Borman, W. C., \& Motowidlo, S. J. (1993). Expanding the criterion domain to include elements of contextual performance. In N. Schmitt, \& W. Borman, (Eds.), Personnel selection in organizations, (pp. 71-98). New York: Jossey-Bass.

Brody, D. C., Demarco, C., \& Lovrich, N. P. (2002). Community policing and job satisfaction: Evidence of positive workforce effects from a multijurisdictional comparison in Washington State. Police Quarterly, 5, 181-205.

Bycio, P., Hackett, R. D., \& Allen, J. S. (1995). Further assessments of Bass's (1985) conceptualization of transactional and transformational leadership. Journal of Applied Psychology, 80, 468-478.

Camp, S. D. (1994). Assessing the effects of organizational commitment and job satisfaction on turnover: An event history approach. The Prison Journal, 74(3), 279-305.

Connelly, M. S., Gilbert, J. A., Zaccaro, S. J., Threlfall, K. V., Marks, M. A., \& Mumford, M. D. (2000). Exploring the relationship of leadership skills and knowledge to leader performance. The Leadership Quarterly, 1, 65-86.

Cropanzano, R., \& Mitchell, M. S. (2005). Social exchange theory: An interdisciplinary review. Journal of Management, 31, 874 $-900$.

Dale, J., \& Fox, M. (2008). Leadership style and organizational commitment: Mediating effect of role stress. Journal of Managerial Issues, 20(1), 109-130.

DeRue, D. S., Nahrgang, J. D., Wellman, N., \& Humphrey, S. E. (2011). Trait and behavioural theories of leadership: An integration and meta-analytic test of their relative validity. Personnel Psychology, 64(1), 7-52.

Dvir, T., Eden, D., Avolio, B., \& Shamir, B. (2002). Impact of transformational leadership on follower development and performance: A field experiment. Academy of Management Journal, 45, 735-744.

Fatokun, A. A. (2007). Influence of job satisfaction and organizational commitment on turnover intention among federal civil servants in Ogun State, Nigeria. Unpublished MMP Thesis, University of Ibadan, Nigeria.

Fleishman, E. A., Mumford, M. D., Zaccaro, S. J., Levin, K. Y., Korotkin, A. L., \& Hein, M. B. (1991). Taxonomic efforts in the description of leader behaviour: A synthesis and functional interpretation. The Leadership Quarterly, 2(4), 245-287.

Flynn, F. J. (2003). What have you done for me lately? Temporal adjustments to favour evaluations. Organisational Behaviour and Human Decision Processes, 91, 38-50.

Gebauer, J., \& Lowman, D. (2009). Closing the engagement gap: How great companies unlock employee potential for superior results. New York: Portfolio.

Howell, J. M., \& Avolio, B. J. (1993). Transformational leadership, transactional leadership, locus of control, and support for innovation: Key predictors of consolidated business-unit performance. Journal of Applied Psychology, 78, 891-902.

Huo, Y. J., Binning, K. R., \& Molina, L. E. (2010). Testing an intelligence model of respect: Implication for social engagement and wellbeing. Personality and Social Psychology Bulletin, 36, 200- 212.

Igbaria, M., \& Shayo, C. (2007). Strategies for managing information system and information technology personnel. Information and Management, 44(2), 188-195.

Islam, T., Khan, S. R., Shafiq, A., \& Ahmad, U. N. U (2012). Leadership, citizenship behaviour, performance and organizational commitment: The mediating role of organizational politics. World Applied Sciences Journal, 19(11), 1540-1552.

John, M. C., \& Taylor, W. T (1999). Leadership style, school climate and the institutional commitment of teachers. International Forum, 2(1), 25-57

Jones, D. (2005). Are you proud of your job? USA Today, May 24, p. B1. 
Judge, T. A., Thoresen, C. J., Bono, J. E., \& Patton, G. K. (2001). The job satisfaction-job performance relationship: A qualitative and quantitative review. Psychological Bulletin, 127, 376-407.

Lambert, E. G. (2004). The impact of job characteristics on correctional staff members. The Prison Journal, 84(2), $208-227$.

Linden, R. C., Wayne, S. J., \& Stilwell, D. (1993). A longitudinal study on the early development of leader-member exchanges. Journal of Applied Psychology, 78(4), 662- 674.

Linz, S. J. (2002). Job satisfaction among Russian workers. William Davidson Institute Working Paper No. 468. Available at SSRN: http://ssrn.com/abstract=313641 or DOI: $10.2139 /$ ssrn.313641

Lok, P., \& Crawford, J. (2001). Antecedents of organizational commitment and the mediating role of job satisfaction. Journal of Managerial Psychology, 16, 594-613.

Macdonald, S., \& MacIntyre, P. (1997). The generic job satisfaction scale: Scale development and its correlates. Employee Assistance Quarterly, 13(2), 1-16.

Macey, W. H., \& Schneider, B. (2008). The meaning of employee engagement. Industrial and Organizational Psychology, 1, 330 .

Macey, W. H., Schneider, B., Barbera, K. M., \& Young, S. A. (2009): Employee engagement: Tools for analysis, practice and competitive advantage. Malden, MA: Wiley-Blackwell.

McBey, K., \& Karakowsky, L. (2001). Examining sources of influence on employee turnover in the part-time context. Journal of Career Development International, 21(3), 136-144

McGuire, M. (2003). Is it really so strange? A critical look at the 'network management is different from Hierarchical management' perspective. Presented at the $7^{\text {th }}$ National Public Management Research Conference, Washington, D. C., October 9-11.

McMahon, B. (2007). Organizational commitment, relationship commitment and their association with attachment style and locus of control. Unpublished Master of Science Thesis, Georgia Institute of Technology.

McNeese-Smith, D. K. (2001). A nursing shortage: Building organizational commitment among nurses. Journal of Health Care Management, 46, 173-186.

McShane, F., \& VonGlinow, S. R. (2000). Organizational behaviour, $2^{\text {nd }}$ Ed. McGraw Hill.

Meyer, J. P., Allen, (1997). Commitment in the workplace: Theory, research, and application. Thousand Oakes, CA: Sage.

Morris, J., \& Sherman, J. (1981). Generalizability of an organizational commitment model. Academy of Management Journal, 24(3), 512.

Mowday, R. T., Steers, R. M., \& Porter, L. W. (1979). The measurement of organizational commitment. Journal of Vocational Behaviour, 14, 224-247.

Noelker, L. S., \& Harel, Z. (2001). Agency scorecard: Promoting quality of care and quality of life. Symposium conducted at the annual meeting of the Gerontological Society of America, Chicago. November.

Nystrom, P. C. (1990). Vertical exchanges and organizational commitments of American business managers. Group and Organization Studies, 15(3), 296-312.

Ogunyinka, M. (2007). Influence of organizational commitment, job involvement and job satisfaction on job involvement among NDLEA officers. Unpublished Master in LCS Thesis, University of Ibadan, Nigeria.

Palakurthi, R. R., \& Parks, S. J. (2000). The effect of selected socio-demographic factors on lodging demand in the USA. International Journal of Contemporary Hospitality Management, 12(2), 135-142.

Piening, E. P., Baluch, A. M., \& Salge, T. O. (2013). The relationship between employees' perceptions of human resource systems and organizational performance: Examining mediating mechanisms and temporal dynamics. Journal of Applied Psychology, 98, 926-947.

Podsakoff, P. M., MacKenzie, S. B., \& Bommer, W. H. (1996). Transformational leader behaviours and substitutes for leadership as determinants of employee satisfaction, commitment, trust, and organizational citizenship behaviours. Journal of Management, 22(2), 259-298.

Robins, S. P. (2003). Organisational behaviour. Upper Saddle River, NJ.: Prentice Hall

Robins, S. P. (2005). Organizational behaviour: Concept controversy and application, $10^{\text {th }}$ Ed. New York: Prentice Hall.

Rusbult, C. E. (1980). Commitment and satisfaction in romantic associations: A test of the investment model. Journal of Experimental Social Psychology, 16, 172-186.

Scandura, T., \& Graen, G. B. (1984). Mediating effects of initial leader-member exchange status on the effects of a leadership intervention. Journal of Applied Psychology, 69(3), 428-436.

Shaiful A., K., Kamaruzaman, J., Hassan, A., Mohamad, I., Kamsol, M. K., \& Norhashimah, A. R. (2009). Gender as moderator of the relationship between OCB and turnover intention. Journal of Asian Social Science, 5(6), 108-117.

Slate, R. N., Wells, T. L., \& Johnson, W. W. (2003). Opening the manager's door: State probation officer stress and perceptions of participation in workplace decision-making. Crime and Delinquency, 49(4), 519-541.

Spector, P. E. (2000). Industrial and organizational psychology: Research and practice. New York, NY: John Wiley \& Sons.

Tewksbury, R., \& Higgins, G. E. (2006). Examining the effect of emotional dissonance on work stress and satisfaction with supervisors among correctional staff. Criminal Justice Policy Review, 17(3), 290-301

Wang, G., Oh, I-S., Courtright, S. H., \& Colbert, A. E. (2011). Transformational leadership and performance across criteria and levels: A meta-analytic review of 25 Years of research. Group and Organization Management, 36(2), 223-270

Wang, H., Law, K. S., Hackett, R. D., Wang, D., \& Chen, Z. X. (2005). Leader-member exchange as a mediator of the 
relationship between transformational leadership and followers' performance and organizational citizenship behaviour. Academy of Management Journal, 48, 420-432.

Wright, P. M., Kackmar, K. M., McMahan, G. C., \& Deleeuw, K. (1995). Cognitive ability and job performance. Journal of Management, 21, 1129-1139.

Zhao, J., Thurman, Q., \& He, N. (1999). Source of job satisfaction among police officers: A test of demographic and work environment models. Justice Quarterly, 16, 153-172. 


\section{NOTES}

